\title{
Synergy in Early Warning Conference: Background
}

\author{
Susanne Schmeidl and Howard Adelman
}

\begin{abstract}
This article provides information on the conference Symergy in Early Warning organized recently by the Prevention/ Early Warning Unit in Toronto, Canada. Included are: background on the issues, a brief outline with the abstracts of the papers delivered and the contact addresses of the authors.

\section{Precis}

Cet article fournit des informations sur le colloque Synergie en Alerte Préventive organisé récemment par l'Unité Prévention/Alerte Préventive de Toronto, Canada. Y figurent: l'historique des problemes, un synopsis du colloque incluant les résumés des communications présentées, et les adresses permettant de contacter les auteurs.
\end{abstract}

\section{Objectives}

In June of 1995, the G-7 summit in Halifax called for the exploration of the means by which to improve the analysis of humanitarian disasters and the utilization of conflict-related early warning information, noting that the issue was not the collection of more information, but the enhancement of analytical capacity, as well as the proc-

Dr. Susanne Schmeidl, former coordinator of the Prevention/Early Warning Unit, Centre for Refugee Studies, York University, is currently a consultant with UNHCR, and as of September 1997, Assistant Professor of Sociology, American University in Washington, D.C.

Howard Adelman is a Professor of Philosophy at York University, Toronto. He was the founder and Director of the Centre for Refugee Studies until 1993, and most recently headed its Early Warming/Preoention Unit.

We gratefully acknowledge financial support by the Social Sciences and Humanities Research Council of Canada (SSHRC), the John Holmes Fund (Department of Foreign Affairs and International Trade), the Canadian International Deoelopment Agency (CIDA), and the Steelworkers Humanity Fund (United Steelworkers of America/Ontario). ess of making analyses available to decision makers. In response to this call, and numerous other within the UN and outside, we organized a conference on the Synergy in Early Warning on March 15-18, 1997. This conference focused on three types of synergies in establishing an early warning network: integrating diverse research methods, combining the organizational efforts of academics, states, international agencies and NGOs, and connecting analyses to strategic responses. This linkage of research, organization, and response will contribute to the early detection, and prevention or mitigation of deadly conflicts. The focus was on intrastate rather than interstate conflicts.

The conference brought together leading academics, policy makers, and representatives of relevant international organizations and NGOs. The integration of policy responses with analysis was intended to increase the capacity of early warning analyses to be sensitive to the needs of policy makers and provide them with specific tools and options.

Initially, the conference tried to address the current split between quantitative and qualitative early warning analyses. By bringing together researchers from both methodological spheres, as well as those academics that have already tried to bridge this gap, the best qualities of both types of research can be combined. While quantitative analysis can furnish the necessary comparative breadth needed for understanding similar structural components of crises, qualitative work provides the contextual sensitivity crucial to understanding specific crises. The conference also addressed the issue of organization and the fragmentation and inadequacy of early warning efforts that have been initiated. Finally, on the policy side, the conference addressed the linkbetween early warning analyses and policy responses. Too often, early warning is undertaken without considering the range of possible responses. The absence of well developed policy options makes it difficult for policy makers to act upon the findings of such analyses.

\section{Relationship to Past, Current and Proposed Research}

This conference built on a series of workshops held over several years at the Centre for Refugee Studies (1991, 1992, 1993) by Professor Howard Adelman, the Center for International Development and Conflict Management at the University of Maryland (1993, 1996) by Professor Robert Ted Gurr and Dr. John Davies, the Department of Foreign Affairs and International Trade, Ottawa (1996), and the Mershon Center for International Security at Ohio State University (1996) by Professor J. Craig Jenkins. These past workshops generally focused only on certain parts of early warning analysis, such as quantitative/qualitative modelling and data systems, without fully attempting to bridge the quantitative/qualitative gap, the organizational issues and the analyses/ response linkages. This conference sought to bridge these gaps.

Initial early warning efforts, particularly in the eighties, focused on humanitarian disasters and concentrated on the collection and analysis of information for the purpose of foreshadowing conflicts with the final goal of mitigating the humanitarian consequences. Early warning was aimed at collecting information to prepare adequate emergency relief. The current focus of early warning is on prevention rather than strictly forecasting, on conflict management rather than humanitarian relief, and on analyses and the development of strategic options rather than just information collection. As such, humanitarian early warning

Refuge, Vol. 16, No. 1 (May 1997) 
requires detailed analysis of three major dimensions: actors, situations, and contexts. Successful early warning also requires a suitable organizational structure and a specific focus on realistic strategic options.

Numerous efforts are underway worldwide to develop early warning models. Some utilize indicators and quantitative models. Others are based simply on sharing field information available from UN agencies and NGOs. Participants in this conference utilized different methodologies and approaches (qualitative analysis versus quantitative computerized coding), in such areas as humanitarian crises, major armed conflicts, genocide/politicide, refugee migrations, and human rights. Much less developed, however, is research on linking responses to early warning signals. The conference tried to bridge this gap by having focused two days exclusively on the linkbetween research and responses and viable policy options.

Despite past efforts, an integrated early warning approach does not yet exist. More recently, however, under the auspices of International Alert, in particular the leadership of Kumar Rupesinghe, Ted Gurr and Hayward Alker, specialists in indicator research, are applying their combined talents to a series of restricted comparative case studies using a model proposed by Alexander George of Stanford University. While their work does attempt to incorporate the issue of responses, structural and organizational issues are still largely overlooked. This conference was an attempt to integrate all of these issues.

\section{The Criteria Used to Select Program Participants}

Guest speakers were selected on the basis of international recognition in early warning research and policy implementation, and their contribution to early warning analysis and response. The most prominent scholars, key decision makers and NGO leaders were selected as guest speakers. Diversity in background and regional origin was also taken into account in order to provide a balanced conference.

\section{Synergy in Early Warning Conference: Brief Outline and Abstracts of the Papers}

Day 1-Sunday, March 16, 1997A. Synergy in Early Warning Research

\section{A-I. Linking Early Warning and Intelligence}
"Defining Humanitarian Early Warning"

Howard Adelman

York Centre for International and Strategic Studies, York University

York Lanes, 3rd Floor, 4700 Keele

Street, North York, ON, M3] 1P3

Canada

Phone: (416) 736-5156

(416) $533-5012(\mathrm{~h})$

Fax: (416) 736-5752

(416) 533-3144 (h)

Email: hadelman@yorku.ca

A lot of effort worldwide is underway to create a system of knowledge and programmatic action based on a concept that may be vague and totally ambiguous-namely "early warning." What is humanitarian early warning about? What benefit does it bring, and how is early warning to be accomplished? We can refer to the long association between early warning and traditional intelligence services which were expected to deliver warnings to their political masters in sufficient time for the political leadership of a state to undertake preemptive action to prevent, deter or, at the very least, mitigate the effects of threatened violent action against one's own state. In the last two decades, early warning has been associated with humanitarian actions rather than protecting against threats to one's country's security. I do not propose to rehearse the development of the concept as it started in humanitarian efforts to anticipate food shortages to enable supplies to be put in place to prevent famine, or the extension of the term to anticipating refugee flows in order to have food and medical supplies as well as tents and water in position to mitigate the suffering of the refugees who generally flee with minimal supplies, and its more latter extension to conflict management to prevent the circumstances which give rise to refugee flows in the first place. Instead, I propose to subject the definition adopted by FEWER, the Forum for Early Warning and Early Response, to a critical examination to unpack its meaning.

\section{"Intelligence and Early Warning: Lessons from a Case Study"}

\author{
Gabriel Ben Dor \\ Department of Political Science \\ University of Haifa \\ Mt. Carmel, 31999 Haifa \\ Israel \\ Phone: $04240050 \bullet 02240050$ \\ 04240599 \\ Fax: 048240050 \\ Email: rspc750@uvm.haifa.ac.il
}

The paper, using the example of the February 25, 1994 shooting spree by an Israeli doctor in a Muslim Prayer Hall in the city of Hebron, tries to answer the question if intelligence should be expected to predict violent events with damaging impact on politics in the future. The case resulted in hearings and deliberation that raised certain points of controversy that provide an excellent case study of early warning, and its link to intelligence. This study addresses itself to these points, based on a study of the material available by the Shamgar Commission, as reported in open sources. No particular distinction is made between the main themes in the hearings on the one hand, and the conclusions and recommendations on the others, as there are no major gaps between them. In addition, particular attention is paid to the linkages between intelligence and early warning, which is a natural theme emerging from the proceedings.

\section{"Potential Humanitarian Crises: The Warning Process and Roles for Intelligence"}

Mary O. McCarthy

National Security Council

The White House

Washington, D.C. 20504

USA 
Phone: (202) 456-9341

Fax: (202) 456-9340

Warning is a process of communicating judgments about threats early enough for decision makers to take action to deter whatever outcome is threatened; or failing that, to manage events in such a way that the worst consequences are mitigated. So in a sense, then, the term "early warning" is redundant; warning that comes too late for action is not warning at all. Intelligence plays a role at each stage in the warning process but it is not intelligence in the traditional sense of stealing or discovering "secrets" that is relevant here. Rather, the intelligence needed in these cases is really information and news. The information may be rather obscure and difficult to obtain, but rarely will the task of diverting or managing a humanitarian crisis depend on discovering secrets. Still, as crises develop, international organizations and NGOs are likely to continue to turn to governments for what they will call "intelligence" on the situation. This will continue to be true because only governments will have the resources devoted to collecting and analyzing the array of information available. Thus, if warning is to be effective, the budding synergy between governments and NGOs will have to blossom as governments and international organizations help provide NGOs with a broad perspective on the crisis and NGOs provide governments with ground truths on areas to which their officials do not have access.

\section{A-II. Quantitative Modelling and Computerized Coding}

"Pattern Recognition for Early Warning: Crisis Classification using Event Data and Hidden Markov Models"

Philip A. Schrodt

Department of Political Science

University of Kansas, 504 Blake Hall Lawrence, KS 66045

USA

Phone: (913) 864-9024

Fax: (913) 864-5700

Email: p-schrodt@ukans.edu
Event data are one of the most widely used indicators in quantitative early warning research. To date, most of the models using event data have constructed numerical indicators of the likelihood and severity of a crisis. These measures are somewhat arbitrary and have yet to gain wide acceptance in the policy community. An alternative approach is to use computerized pattern recognition techniques to match an existing crisis to a set of similar historical cases, and use those historical cases to judge the likely severity of the current situation. This approach has much in common with the techniques used by human analysts-who frequently employ reasoning by historical analogy-while preserving the advantages of the inexpensive and systematic monitoring that is possible using contemporary methods of automatically generating event data from newswire reports. This paper reports on a project that uses "Hidden Markov models," a recently developed sequence-comparison technique that is widely used in computational speech recognition, to measure similarities among international crises. The model is developed using the "Behavioural Correlates of War" data set of historical crises, then applied to political behaviour in the contemporary Middle East.

\section{"Mapping Mass Political Conflict and Civil Society: Issues and Prospects for the Automated Development of Event Data"}

Doug Bond (Harvard University), J. Craig Jenkins (The Ohio State University), Charles Taylor (Virginia Polytechnic Institute and State University) and Kurt Schọck

(Rutgers University)

The Center for International Affairs

Harvard University

1737 Cambridge Street

Cambridge, MA 02138

USA

Phone: (617) 495-7705

Fax: (617) 496-8562 • 495-8292

Email: dbond@cfia.harvard.edu
Mass political conflict is examined typically in terms of violence and in isolation from routine civil interactions. We argue that mass conflict is multidimensional and that violence should be treated as an outcome of conflict, as well as a form of action. We define three dimensions of conflictcontentiousness, coerciveness, and change goals-and indices of the civil society that are central to mapping global trends in mass conflict. We then outline a strategy for mapping mass conflict and civil interactions using the PANDA protocol to generate highly reliable event data and then use these indices to trace two democratic transitions (in Poland and South Korea), a conflict crisis that was repressed (China) and a conflict escalation that flared into a civil war (the former Yugoslavia). Automation has major advantages over human coding in terms of transparency, integration with existing event data series, real time availability and long-term maintenance costs. It also opens up new ways of thinking about event data and the assessment of reliability.

\section{"Assessing Risks of Ethnorebellion in the Year 2000: Three Empirical Approaches"}

Will H. Moore (University of California) and Ted Robert Gurr (University of Maryland)

Department of Political Science University of California, Riverside P.O. Box 3138, Idyllwild, CA 92549 USA

UCR voice: (909) 787-6367

UCR fax: (909) 787-3933

Home voice/fax: (909) 659-2467

Email: will.moore@ucr.edu

This paper describes three empirical approaches to generating risk assessments of ethnorebellion from 1991-95 data on 268 groups surveyed in the Minorities at Risk project. The results are compared with one another and, in high risk cases, with recent political developments. The approaches are risk profiling (based on a priori specification of risk factors), theoretical modelling, and empirical modelling, the

Refuge, Vol. 16, No. 1 (May 1997) 
latter two based on analysis of residuals from regression analysis. We distinguish risk assessments from early warnings and forecasts. Rather than estimating precise probabilities of ethnorebellion, we offer three alternative assessments of risks of rebellion in the mid-range future. These assessments are expected to hold only if the variables identified in the risk profiles remain constant-which, in a changing political world, is not likely. Qur assessments should be useful because they identify key variables and high risk cases that warrant monitoring. Such monitoring CAN provide early warning, thus our assessments provide a foundation for the development of early warning systems of ethnopolitical conflict.

\section{"Accessing and Analysing of E-Mail Reports Through Database Systems"}

\section{Valery Stepanov}

Centre for Study and Prevention of Conflict, Institute of Ethnology and Anthropology

Leninskii Prospect 32a

117334 Moscow

Russia

Phone: (095) 938-0043

Fax: (095) 938-0043

Email: anthpub@iea.msk.su

The presentation aims to discuss an idea hypertext for improving system of query statements to database on ethnic conflict topics. The Centre for the Study of Conflict (Institute of Ethnology and Anthropology, Russian Academy of Sciences) coordinates a wide-range email early warning network. The Centre accumulates, processes and publishes essential information received from more than 20 geographical areas of the former Soviet Union. For this purpose special database is being developed in the Centre. We describe two main applications for database management. It offers new opportunities for scholars and practitioners in fast overviewing data and generating new ideas.

\section{A-III. Qualitative Analysis and Case Studies}

"Early Warning for North Korean Flood Victims at Refugee Risk: Victims of Nature or Politics?"

Shin-wha Lee

Graduate School of International

Studies, Korea University

799-10 Bang-Bae Dong

Seo-Cho Ku, Choong Ahng Hts Villa, \#201, Seoul

South Korea

Phone: (822) 599-2763 • 594-2763

Fax: (822) 599-2763 • 521-8805

Email: swlee@kuccnx.korea.ac.kr

In the event of the recent floods which aggravated the seriousness of existing food supply problems in North Korea, the concerns related to possible instability on the Korean peninsula have revolved around the possibility of North Koreans at refugee risk. The need for contingency planning is required to prepare for massive refugee flows that might result from further economic decline and or famine in North Korea. Yet, efforts to do everything possible to halt refugee flows by stabilizing the agricultural production and feeding people in at-risk areas are more desirable, since refugee flows mean a following indicator, not a leading indicator, of insecurity. The case of North Korea, however, represents limits of early (or preventive) action due to various obstacles such as sovereignty, political propaganda ('Chu-che'), and misinformation. Citing the country's food crises initiated by natural disasters (floods) and aggravated by political manipulation, this paper will examine: under what condition is early detection difficult?; under what circumstances are preventive actions less feasible though the early warning models are successful and the crises are detected in a timely fashion? In the case of North Korea, categorizing environmental factors alone is not feasible. A comprehensive analysis is needed for comparing the natural factors causing the country's food crisis with the political factors.

\section{"Early Warning: The Case of the Former Soviet Union"}

Valery Tishkov and Mara Ustinova Institute of Ethnology and Anthropology, Russian Academy of Science Leninskii Prospect 32a

117334 Moscow

Russia

Phone: (7 095) 938-1747 • 938-1917

Fax: (7 095) 938-0600

Email: mara@eawarn1.msk.su

Early warning of conflicts in the former USSR dates its origins to 1993, when the Network of Ethnological Monitoring and Early Warning of Conflict (EAWARN) was formed within the framework of the international project "Ethnic Conflict Management in the Former USSR". The project is coordinated by the Institute of Ethnology and Anthropology, Russian Academy of Sciences, and Conflict Management Group, Harvard Law School, in cooperation with the International Laboratory of Mass Communications (VEGA). The project is funded by the Carnegie Corporation of New York and the Russian Academy of Sciences. The EAWARN is a network of leading experts in the former Soviet Union, including a number of Russia's republics and administrative regions with multi-ethnic populations and conflict situations. The Network is designed to monitor ethnopolitics, to collect and process information for early detection of potential conflicts and early preventive action. The Founding Director of the EAWARN is professor Valery Tishkov. Inaugurated on September 1 , 1993, the Network includes over 25 local experts now. The goal of this presentation is to share the experience of building the Network and its development. The following issues will be explored: the specific elements of the Network's development stages from initial information sharing to current descriptive analysis of Early Warning model, based on 47 indicators; professional and personal characteristics of the local representatives who gather information and their affect on the type 
of information; use of information collected for political recommendations.

$$
\begin{gathered}
\text { "Research of Socio-Psychological } \\
\text { Factors in a System of Early } \\
\text { Warning" }
\end{gathered}
$$

Eugeni V. Kritski

Director, North Caucasian Centre Institute for Social and Political Research

Russian Academy of Science P.O. Box 63, 350048 Krasnodar Russia

Phone: (861-2) 59-14-17

Email: kritski@eawarn.kuban.su

One of the major elements of the early warning of ethnic conflicts is the empirical data collecting through quantitative research of mass consciousness in regions of potential conflict. The report presents an experience of the North-Caucasian Centre of the Institute of Social and Political Research of Russian Academy of Sciences in studying socio- and ethno-psychological background of the potential conflicts in a region of Northern Caucasus. The region located in South-West Russia is a specific frontier between Western and Eastern civilizations and due to this fact involved not only in the Russian field of geopolitical interests but in those of Turkey, Iran, Trans-Caucasian countries and Muslim world as a whole. The structure of the Chechen conflict was observed as a phenomenon presented by focal events, induced directly by contradiction of values and interests of fighting sides, as well as peripheral events -consequences determined by catalysing influence of open violent conflict in Chechnia upon political, social, ideological and sociopsychological developments in neighbouring republics with their own conflictogeneous potential. Peripheral events could provide favourable conditions for penetrating "external" conflict and for genesis of a new one. In an applied quantitative research, we tested a hypothesis about probable types of behavioural reaction in peripheral societies determined by stereotypes of the conflict perception (a specific test on value compatibility and tolerance between different ethnic and social groups). The first type of reaction was indicated by features of consolidation of the peripheral society on the base of solidarity with one of the fighting sides, which could provoke a conflict with another; the second was indicated by tendencies to fragmentation of the society on the basis of differences in conflict perception, which could lead to sharpening of social (interethnic) relations and transform a conflictogeneous situation into conflict.

\section{A-IV. Synergy of Qualitative Studies with Quantitative Models}

\section{“Dynamic Data for Conflict Early Waming"}

John Davies (University of Maryland) and Barbara Harff (U.S. Naval Academy)

Centre for International Development and Conflict Management, University of Maryland 0121 Tydings Hall, College Park, Maryland 20742-7231

USA

Phone: (301) 314-7709

Fax: (301) 314-9256

Email: JD71@umail.umd.edu

The paper examines the need for systematic model-based early warning systems, supported by dynamic and structural data systems. It introduces GEDS as one such dynamic data system and outlines the accelerator categories developed by Harff for the use in early warning models for genocide and ethnic conflict. The paper also reports some results testing the efficacy of such accelerators.

\section{"Early Warning and Deterrence Strategies: States versus Institutions"}

David Carment (Dalhousie University) and Frank Harvey (Carleton University)

NPSIA, Carleton University

Level 2A Paterson Hall, 1125 Colonel By Drive
Ottawa, ON, K1S 5B6

Canada

Phone: (613) 520-2600 ext. 6662

Fax: (613) 520-2889

Email: dcarment@ccs.carleton.ca

There is no definitive evidence on when and under what conditions third parties should intervene in a coercive way to prevent ethnic tensions from escalating out of control, or how to manage crises when they do. Nor do we clearly understand the conditions under which deterrent and compellent threats (or any form of coercive diplomacy, for that matter) will succeed or fail, or how credibility and resolve are influenced by (a) the "type of intervener," (b) "the type of conflict," or (c) the "stage" at which the intervention takes place. Even more disturbing is the fact that answers to these questions are becoming crucial at a time when international relations theory is being criticised for its lack of cumulativeness, or, even worse, relevance. With respect to deterrence theory, the most widely researched form of coercive diplomacy and the focus of our study, there are no clear and consistent findings. Without an empirical base to evaluate the conditions under which coercive diplomacy is likely to succeed, answers to pressing questions about the onset, escalation and resolution of ethnic conflict and violence will remain elusive. Our paper has three interrelated objectives: 1) to explore the nature of ethnic conflict de-escalation in the context of deterrence theory, 2) to produce policy relevant information on the success rates of different types of third party interventions, 3) to assess the impact of "crisis profiles" (ethnic/non-ethnic; interstate/intrastate) on the probability of success, and 4) to examine the larger implications for early warning and preventive diplomacy. Two propositions are tested against crisis data: 1) multistate coalitions are more likely than unilateral interveners, and unilateral interveners more likely than IOs, to control hostilities in both ethnic and non-ethnic crises; 2) multistate coalitions are more likely than unilateral interveners, and 
unilateral interveners are more likely than IOs, to control hostilities in both interstate and intrastate crises.

"The Systemic-Evolutionary

Extended Signal Approach"

\section{Andrea K. Riemer \\ Political Consultant}

Veronikagasse 38/230, A-1170 Wien

Austria

Phone/Fax: +4314001729

Email: smutek@isis.wu-wien.ac.at

The period after 1989 has been the most turbulent and erratic since World War II. All areas of our society show far reaching signs of transformation. We are living in an "Age of Discontinuity." To analyze and assess discontinuities (global level) and crises (regional level) which may rise from changes in the areas of demography, economy, ecology, technology and politics/religion, the following approach is presented and applied to the question: "Is there a potential for crisis if ethnic minorities are not sufficiently integrated into the state?" The Kurds have been one of the largest minorities in the world for years. "Kurds" is a term comprising several groups of clans living in a divided area. By far the largest number of Kurdish clans live in Turkey. The "Turkish Kurds" have been showing a high potential for crisis for about fifteen years. The conflicts between the PKK and the Turkish government and the Army show several features of a civil war costing the lives of the civilian population. Moreover, the conflict has cost Turkey face in the international arena as well as a lot of money (about 6 to 7 million US dollars per year).

\section{"Combining Indicator Research and} Case-Based Analyses"

\section{Adeel Ahmed and}

Elizabeth V. Kassinis

Department of Humanitarian Affairs

United Nations

New York, NY 10017

USA

Phone: (212) 963-1249

Fax: (212) 963-1314
Email: ahmeda@un.org

kassinis@un.org

While it is clear that if crises could be prevented, lives and scarce resources would be saved, there is much less clarity with regard to "prevention" as a concept and "early warning" as a tool. While prevention has proven to be an elusive goal, early warning continues to receive increased attention, with the term used to describe an increasing number of different, and differing, activities. For the last three years, the United Nations Department of $\mathrm{Hu}$ manitarian Affairs (DHA) has been struggling to turn early warning from a sound concept into a series of implementable and fruitful activities. This has included defining what early warning is; how it can be operationalized; and most importantly, how it can be used to initiate early and effective action on the part of the UN and the humanitarian community. The $\mathrm{Hu}-$ manitarian Early Warning System (HEWS) was established to identify crises with humanitarian implications, recognizing that the causes of crises are as numerous and complex as the implications themselves. This paper will trace the evolution of thinking within DHA on the tools, mechanisms, and processes needed to accomplish the task. In particular, it will examine the balance required between indicator analysis and case-based research to support decision making within an organization such as the UN. Striking such a balance is critical, in order to translate analyzes derived from systematic indicator research into viable and practical policy options for decision makers.

\section{A-V. The Media and Early Warming}

\section{"Propaganda and Genocide"}

Frank Chalk

Department of History

Concordia University

1455 De Maisonneuve Blvd. West

Montréal, PQ, H3G 1M8

Canada
Phone: (514) 848-2404

Fax: (514) 848-4538

Email: drfrank@alcor.concordia.ca

This paper offers a preliminary comparative historical examination of the role of state and regime-supported propaganda in inciting civilians to implicate themselves in genocides and gross violations of human rights through participation and/or acquiescence in killings. Reviewing past cases in light of mass participation in the Rwanda genocide of 1994, it examines the twentieth century genocidal killings of Armenians, "kulaks" and "bourgeois elements" in the Soviet Union, Jews, Indonesian Communists, Cambodians, and several groups of victims in the former Yugoslavia. Conclusions are drawn regarding the techniques adopted by the perpetrators to demonize the victims, the role of the media of the time in mobilizing mass support for the killings, and the contributions of communication theories to understanding the circumstances under which victims become vulnerable to propaganda. Questions for future research are posed.

\section{“U.S. Television Network Coverage on Humanitarian Crises: Can they be a Source of Early Warning?"}

\section{Steven Livingston}

School of Media and Public Affairs

The George Washington University

801 22nd Street, N.W.

Washington, D.C. 20052

USA

Phone: (202) 994-5888

Fax: (202) 994-5806

Email: sliv@gwis2.circ.gwu.edu

Livingston's remarks will focus on the response of American television news to humanitarian emergencies. He will focus on two interrelated questions: To what extent might we reasonably expect American television networks, including $\mathrm{CNN}$, to serve as a reliable source of information regarding nascent or even extant refugee crises? Secondly, what role might media play in the humanitarian policy responses of the United States government? While 
considerable expectation is sometimes placed in media, particularly television, to serve as response catalysts in humanitarian crises, a close and careful examination of the evidence garnered from recent humanitarian crises suggests prudence in developing these expectations.

\section{"The Media in Conflict Prevention and Management: Curse or Catalyst?"}

Nik Gowing

BBC-Word Television

London

England

Phone: +44-181-225-8119

Voice: +44-181-576-8137

Mobile: +44-802-877-808

Home: +44-802-741-5083

Fax: +44-181-287-4427

Email:

100523.2530@CompuServe.com

Much is expected of the media in conflict prevention and management. The reality is different from the expectation. Based on new work for the Carnegie Commission on Preventing Deadly Conflict, this paper analyzes the myths of the media's role in early warning. How accurate, how partial and therefore how credible is real-time reporting in the build up to, and prosecution of a conflict?

Day 2-Monday, March 17, 1997 B. Synergy in Organization

\section{B-I. Governments and Early Waming}

"How to Establish an Early Warning System: Concept and First Steps in Switzerland"

Andreas V. Kohlschütter and

Günther Bächler

Swiss Peace Foundation

Wasserwerkgasse 7, P.O. Box

CH-3011 Bern

Switzerland

Phone: +41313115582

Fax: +41313115583

Email: spfbaechler@dial.eunet.ch
The authors introduce a pilot project on a general conflict warning system mainly designed to serve the Swiss Foreign Ministry. Especially after the Rwanda disaster the administration (backed by the Foreign Committee of the Parliament) underlines the need for a computerized system that builds the ground for early recognition and, thus, enhances the "institutionalized" pressure to (re)act in a stage of a conflict as early as possible. Questions arise on the state of the art as well as on the interface between early warning on one hand and decision making and early action on the other.

\section{B-II. The Role of the UN and UN Organizations in Early Waming}

\section{"Early and Late Warning of Acute Conflict by the UN Secretary-General"}

\section{A. Walter Dorn}

International Relations Programme

University of Toronto

Trinity College, 6 Hoskin Avenue

Toronto, ON, M5S $1 \mathrm{H8}$

Canada

Phone: (416) 978-5217

Fax: (416) 978-2797

Email: wdorn@chem.utoronto.ca

The only political role that was explicitly given to the Secretary-General in the UN Charter is early warning. (Under Article 99, he/she may bring threats to the peace to the attention of the Security Council.) But can the UN Secretary-General actually succeed in providing early warnings? By digging into the mines of UN history, I have sought to identify and tabulate the various roles played by the Secretary-General, and to highlight the instances of early warning. For over 100 conflicts examined, only a very few (e.g., Congo 1960, Bahrain 1970, Macedonia 1992) can be rigorously classified as early warning. These provide some useful pointers. The many cases of late warning (e.g., Korea 1950, Falklands/Malvinas 1982, Namibia 1989) can also yield valuable learning. Fur- thermore, there are only three or four explicit invocations of Article 99 and about a dozen cases of implied invocations, though most would be considered "late" warnings. This paper will summarize the constraints and opportunities for early warning in each of its three stages (information gathering, analy sis and dissemination), and make suggestions about how some obstacles can be overcome. For technical and political reasons, the UN SecretaryGeneral is now in a better position to do early warning than ever before but certain improvements are still called for: better targeting of desired information, increased intelligence-sharing, tighter confidentiality systems, easier access for on-site observation, a stronger analytical capacity (including scenario building), quicker feedback at headquarters and a more proactive approach in issuing warnings and undertaking response measures. This may be a tall order at a time when the international community seems unwilling to increase the UN's staff and resources but the goal of conflict prevention is worthy of all such efforts.

\section{"Early Warning of Violent Conflict: The Role of Observer Missions"}

Major David M. Last

The Lester B. Pearson Canadian International Peacekeeping Training Centre

Cornwallis Park, P.O. Box 100

Clementport, NS, BOS 1E0

Canada

Phone: (902) 638-8611 ext. 144

Fax: (902) 638-3310

Email: dlastoppc.canpeacekeeping.ns.ca

Military and civilian observers have been deployed by the United Nations and by Regional Organizations for a variety of purposes at various stages in the escalation and de-escalation of tensions. How can observer missions enhance early warning of violent conflict? Recent observer missions in the Balkans, Africa and Central Asia have relied heavily on military personnel. They have often been deployed after it is evident that violent conflict is likely, or is in progress. Often, the informa-

Refuge, Vol. 16, No. 1 (May 1997) 
tion they provide at considerable risk has added little to the international community's ability to respond to or prevent violent conflict. With knowledge about how conflicts start and spread, we can link observer missions more effectively to other means of early warning. If they are structured, trained, and deployed to address the many dimensions of incipient violence, they can be used to help galvanize international response. This may entail linking observer missions to projects like the Forum on Early Warning and Emergency Response (FEWER), to permit mutual support. Adding police, judicial, socioeconomic, political and media analysis elements to observer missions would increase their capacity to observe nonmilitary dimensions of incipient conflict. Missions might normally be structured with military observers in support of these elements. Providing high-level liaison officers from the observer mission to international bodies might allow the international community to respond more effectively, and lend added credibility to the mission's activities. In conjunction with international bodies, a mission media cell could help shape the international view of an emerging crisis, the better to manage response. Observer missions can help with both early warning and international response to incipient violent conflict. The next generation of observer missions should have multifunctional headquarters with analysis and assessment units, liaison to international bodies, effective team preparation, and realistic media strategies.

\section{"Averting Famine Through Linking Early Warning with Response Mechanisms"}

Abdur Rashid

Food and Agriculture Organization of the United Nations

Chief Global Information and Early

Warning Service Commodities and

Trade Division, Room D-886

Viale delle Terme di Caracalla

00100 Rome

Italy
Phone: (39-6) 52253 099/3144

Fax: (39-6) 52254495

Email: abdur.rashid@fao.org

FAO's Global Information and Early. Warning System (GIEWS) has been assigned the mandate of constantly monitoring the Global food supply and demand situation and alerting the international community to countries or regions threatened by serious food shortages or which have exceptional surpluses of food requiring donor assistance for disposal. In a period when the number and complexity of food emergencies has been growing, GIEWS continues to provide policymakers and relief agencies throughout the world with the most up-to-date and accurate information available. Yet having an effective early warning system is no guarantee that timely and adequate interventions will follow. Emergency assistance is not always mobilized in sufficient volume, or it arrives too late to avert famines and save lives. However, objective early warning information continues to play a crucial role in ensuring that timely and appropriate action can be taken to avoid human suffering and loss of life. The paper outlines GIEWS experience in linking early warning with response mechanisms in some recent food emergencies. It shows how effective early warnings, rapid national/regional coordination and adequate international support have resulted in successful relief effort which averted threats of famine and saved many lives.

\section{B-III. The Role of NGOs in Early Warning}

"Eyes and Ears? Limits of NGO Information for Early Warning"

\section{William DeMars}

Political Science Department

The American University in Cairo

P.O. Box 2511, Cairo, 11511

Egypt

Phone: (202) 357-6782 (w)

Fax: (202) 355-7565

Email: wedemars@acs.auc.eun.eg
Complex humanitarian emergencies generate human rights abuse, famine, disease and displacement on a massive scale, and they are almost invariably rooted in civil wars. The link between civil war and humanitarian catastrophe was a common factor in Biafra, Cambodia, Ethiopia and other Cold War disasters, and it remains a feature of post-Cold War emergencies as exemplified by events in Somalia, Bosnia and Rwanda. Policy responses to internal conflicts have passed through several phases since 1989. First, the withdrawal of superpower sponsorship from proxies failed to eliminate all civil wars. Next, muscular military humanitarianism stumbled in Somalia and Bosnia. Finally-and with a degree of desperation born of growing isolationism in public opinion-policymakers in governments, the UN and NGOs have turned to "early warning and conflict prevention" as a rationale for global internationalism at a discount price. The body of the paper consists of three sections. It first examines the limits of NGO information on internal conflicts, and several means to overcome those limitations. The next section describes recent initiatives to share intelligence for early warning in policy networks that include NGOs and elements of the U.S. national security bureaucracy. The third section addresses specific cases and issues of such policy networks.

"NGOs and International Relations Theory: The Rwanda Case"

Janice Stein (University of Toronto) and Bruce Jones (London School of Economics)

Department of Political Science

University of Toronto

Sidney Smith Hall

100 St. George Street

Toronto, ON, M5S 1A1

Canada

Phone: (416) 978-1048 • 978-6758

Fax: (416) 978-5566

Email: jstein@chass.utoronto.edu

The authors analyze the role of NGOs in providing early warning of the genocide in Rwanda in order to shed 
light on the strengths and weaknesses of NGOs as ringers of warning bells generally. The authors begin by arguing that on the basis of obvious structural virtues as organizations, NGOs should have some specific advantages in the capacity to provide early warning. However, the authors conclude that the Rwanda experience does not indicate that such capacities are in fact being employed. In order to capitalize on crucial assets NGOs possess in general and, in fact, did possess in Rwanda, the NGO community would have had to: 1) maintain and deepen its connection with local communities throughout an emergency which sapped NGOs energies and preoccupied its leadership; and 2) understand at both policy and operating levels the high value of the assets it had and the importance of applying them to international processes of early warning.

\section{B-IV. New Approaches to Collaborative Early Warning Information, Analyses and Network Systems}

\section{"RefWorld as an Early Warning Tool"}

\section{Udo Janz}

United Nations High Commissioner for Refugees, Information and

Research Management

UNHCR/CDR

Case postale 2500

CH-1211 Geneva 2 Depot

Switzerland

Phone: +41 227398555

Fax: +41227397367

Email: janz@unhcr.ch

Reliable information from a variety of tested sources within the public domain that have withstood the challenge of corroboration and verifiability over time, inevitably forms the backbone of any analytical attempt at early warning in humanitarian crises situations. Speedy access to this information has been considerably enhanced over the past years as an increasing number of governments, inter-governmental and non-governmental organizations make the information they generate available through the World Wide Web in addition to hard copy dissemination. Although extremely useful for its currency, the Web does however still pose limitations with regard to carrying out efficient searches of less time sensitive information that may nevertheless be crucial to assess for early warning purposes. Since the early 1990s, UNHCR has embarked on a project of converting large amounts of critical information relating to the international refugee regime, situated in the broader human rights context, and consisting of legal and country information, from hard copy into electronic format for dissemination to its field offices worldwide and the public at large. This project, known as RefWorld, has in the meantime come to fruition and the combined databases are available already in its 3rd edition on CD-ROM since January 1997 with a complementary edition available through UNHCR's home page on the World Wide Web. The end product probably constitutes the most comprehensive refugee and human rights information resource available to date, including many early warning benchmark reports on country situations around the world that are not available elsewhere in electronic format. RefWorld is also the result of unprecedented collaboration among a great variety of actors in the humanitarian and human rights fields with UNHCR, and its success can be attributed to all who had the vision and the determination to contribute to this endeavour even in the face of seemingly insurmountable obstacles.

\section{"Early Warning and Information: The Role of ReliefWeb"}

\section{Sharon Rusu}

Department of Humanitarian Affairs United Nations

8-14, avenue de la Paix

CH-1211 Geneva 10

Switzerland

Phone: +41 229172661

Fax: +41229170023

Email: sharon.rusu@dha.unicc.org
If the current humanitarian emergency in the Great Lakes has taught us anything, it is that we do not have an effective international system for intervention in humanitarian emergencies. Following the previous crisis in Rwanda in 1994, lessons learned stressed the need for an early warning system whose warnings would result in the initiation of appropriate responses on behalf of those displaced by conflict and coercion. How do the current policy-oriented approaches in early warning support or hinder the humanitarian community in transcending what has been described as the dilemma of humanitarism in the '90s? This paper will comment on several current approaches with a view to assessing the role of ReliefWeb, a global information system developed and maintained by UN Department of Humanitarian Affairs as part of its efforts in early warning.

\section{Day 3-Tuesday, March 18, 1997- C. Synergy of Analyses and Responses}

\section{C-I. Early Responses}

\section{"The Paradox of Prevention: Successful Prevention Erases the Proof of its Success. A Case for A New Ethic of Evaluation"}

Jean Guilmette

International Development Research Centre

250 Albert Street, P.O. Box 8500

Ottawa, ON, K1G 3H9

Canada

Phone: (613) 236-6163

Fax: (613) 561-4349

Email: jguilmette@idrc.ca

Populations tend to become increasingly more conservative and risk adverse when it concerns the usage of tax revenues. The level of acceptable risk premium may vary from society to society, of course, but there is always a measure of "non rational" decision taking. A critical question is: "how risk adverse is the general population when it judges the performance of its 
government, of its administration and its civil servant?" And conversely, "how deep a risk aversion runs in the bureaucracy? In the Government?" Consequently "How much of a risk premium is Parliament and the Administration ready to charge the taxpayers to avoid any possibility of errors leading to political embarrassment?" Or "how irrational has its behaviour become?" The purpose of the following reflections is to attempt to decipher the specific "system of rationality" that has come to govern Foreign Affairs and Aid decisions in the recent past. Especially as they influence the decision taking for complex problems such as conflict prevention in Africa. I will first attempt to explain why prevention is difficult to undertake. I will show why managers refrain from taking high risk decisions after they have been subject to critical comments by evaluators and how they learn to cope in very specific manners: their selection of choices become increasingly more irrational. This is, of course, the contrary reaction expected by the evaluators whose primary intentions are to increase rationality in decision making. Among solutions that could be envisaged, one should spend some time assessing the impact and role that evaluation plays in the build-up of such increasing risk premiums. A new dimension must be added to the ethical code of evaluators which would take into consideration the direct effect of the evaluator's own behaviour."

\section{"IOM and Early Responses"}

William Hyde

International Organization for

Migration (IOM)

17 , route des Morillons

CH-1211 Geneva 19

Switzerland

Phone: +41227179111

Fax: +41 227986150

Email: hyde@geneva.iom.ch

The International Organisation for Migration (IOM) has the objective to ensure the orderly migration of persons in need of international assistance. IOM is an intergovernmental membership organization with 59 Member States and 48 Observer States. IOM enjoys a close working relationship with many UN agencies, other IOs and NGOs working in humanitarian assistance. The IOM Emergency Response Unit (ERU) was established to (a) develop policies, practices and resources in order to respond more effectively to organizationally determined emergency needs and (b) to initiate or support emergency response efforts. Building on relevant materials of others, and adapting and supplementing them through IOM's unique experiences, the ERU has developed several course books and guides for internal staff training in emergency operations. Regular Workshops are facilitated for IOM staff both at Headquarters and field locations, in order to prepare for better response. The ERU participates in various $\mathrm{UN}$ and other interagency/ interorganizational bodies dealing with better humanitarian response.

\section{"Quantitative Approaches to Sovereign Risk Analysis: Implications for IMF Responses"}

Dane Rowlands

NPSIA, Carleton University

Level 2A, Paterson Hall

1125 Colonel By Drive

Ottawa, ON, K1S 5B6

Canada

Phone: (613) 520-2600 ext. 8884

Fax: (613) 520-2889

Email: drowland@alfred.carleton.ca

Increased financial integration has been accompanied by greater volatility of capital flows. For many less developed countries (LDCs) this volatility can have serious economic repercussions. The International Monetary Fund (IMF) has been assigned an important role in dealing with the problem through emergency lending and enhanced surveillance duties. Predicting these crises, however, is difficult. The paper begins by outlining the task which the IMF has been directed to undertake, and why "early warning" is essential to fulfilling the mandate. A brief review of the literature on the use of early warning models to predict fi- nancial crises is then provided. The paper then provides some preliminary evidence on the relative value of systemic and country-specific analyzes in managing IMF resources.

\section{C-II. Linking Early Waming Research to Responses I \\ "Towards Response-Oriented Early Warning Analysis: Policy and Operational Considerations"}

\section{John Cockell}

Department of Foreign Affairs and International Trade

Peace-building and Human Development Division (AGP)

125 Sussex Drive

Ottawa, ON, K1A 0G2

Canada

Phone: (613) 995-7800

Fax: (613) 944-1226

Email: john.cockell@extott07.x400.gc.ca

The connection between conflict early warning and early response is here explored as a problem of policyrelevant analysis. The paper argues that while many advocates and researchers in the early warning field decry the absence of "political will," the fact remains that much of what currently exists as early warning is not adequately presented to policymakers. This involves both clear analysis of critical trigger factors, and better targeting of these analyzes such that they are readily utilised by policy endusers. The paper argues that current conflict early warning practices are not effective in presenting dynamic analysis that prioritizes factors and presents practical options for preventive peacebuilding. To illustrate this argument, a framework for early warning analysis is outlined in brief. Based on ongoing research in the Canadian foreign ministry, this framework focuses on seven political early warning categories: status of governance/political process; polarisation/potential for conflict; structural/societal tension; human rights violations; military/arms supply; external support; and contextspecific considerations. Improvements in policy response-oriented 
analysis will demand better interaction between early warning researchers, field monitors, and policy analysts in governments, aid agencies, and regional and international organizations. The paper concludes with some observations in this regard, and a brief review of some existing initiatives which perhaps embody this sort of interaction. Written from the perspective of a conflict analyst in the Canadian foreign ministry, the paper is informed by current policy and operational requirements for "early response" and preventive peacebuilding.

"Bridging the Gap between Warning and Response: Approaches to Analyzing Effective Preventive Interventions"

Michael S. Lund

Center for Strategic and International Studies and Creative Associates

International, Inc.

Creative Associates

Greater Horn of Africa Project

5301 Wisconsin Ave. N.W., Suite 700

Washington, D.C. 20015

USA

Phone: (202) 966-5804 ext. 114

Fax: (202) 363-4771

Email: mlund@caii-dc.com

Early warning data systems have been proliferating for some years and are gaining validity. But analysis of what individual and multiple responses are effective in preventing violent conflicts has begun only recently. Until high-level policymakers have received authoritative analyses of what preventive interventions work under what circumstances, we cannot say whether their failures to respond arise from lack of will or lack of a way. The knowledge policymakers can use involves several key action-oriented questionswhen? what? why? who? how? and whether? - but existing early warning research addresses these only partially. The paper discusses the units of analysis that might be most useful for codifying recent preventive experience, impact criteria, and two forms of such analysis that might provide policy relevant answers to the action questions. These forms are evaluations of differing policy tools of intervention (e.g., preventive deployment, conditional development aid), and casestudies of successful and unsuccessful multi-tooled preventive interventions (e.g. Macedonia, Burundi). How this knowledge might be incorporated into the country-level strategic plans of donors and other third parties is discussed. The resulting idea of "rolling" prevention, rather than the prevailing "alarm bell" model, is offered. Evidence and examples are drawn from recent case-study research on paired successes and failures, tools' work done for the U.S. Greater Horn of Africa Initiative, and evaluation of development aid's effect on conflict.

\section{"Armed Conflicts and Human Right Violations: PIOOM's World Conflict Map 1996"}

A. P. Schmid and A. J. Jongman

PIOOM, Leiden

Wassenaarseweg 52

2333 AK Leiden

The Netherlands

Phone: + 31 (0) 715273861

Fax: +31 (0) 715273788

Email: schmid@rulfsw.leidenuniv.nl

Since 1993 PIOOM has been monitoring armed conflicts on three levels of intensity, using a broader definition of war than some other monitors like SIPRI (Stockholm) or AKUF (Hamburg). The result is a somewhat less optimistic overall assessment of the world conflict situation. The paper presented explains and comments upon a new version of the PIOOM Conflict Map, which contains new dimensions, partly generated by PIOOM itself, partly synthesized from other sources.

The paper discusses the following variables and indicators:

1. Conflict Levels;

2. Confirmed and Suspected Presence of Weapons of Mass Destruction;

3. Countries Severely Infested with Land Mines

4. Use of Child Soldiers in Conflicts;

5. United Nations and Regional Peacekeeping Operations;
6. Refugees and Internally Displaced

People by Country of Origin;

7.States of Emergency;

8. Level of Political Terror under Severely Repressive Regimes;

9. Military Rule;

10. Coups d'Etat and Army Mutinies;

11. Presence of Systematic Torture;

12. Annual and Cumulative Fatality Figures for High Intensity Conflicts;

13. UN and other Peacekeeping Operations;

14. Use of the Death Penalty;

15. Food Security; and

16. Human Development Index.

\section{C-III. Linking Early Warming Research to Responses II}

"Institutions for Managing Ethnic Conflicts: Selected Cases"

Jacques Bertrand

The North-South Institute

55 Murray Street, Suite 200

Ottawa, ON, K1N 5M3

Canada

Phone: (613) 241-3535

Fax: (613) 241-7435

Email: jbertran@web.net

What kinds of actions can help to reduce conflict before it becomes violent? There are an array of possible measures that exist, from dialogue and mediation to sending peacekeeping troops. Which measures are appropriate and effective depends on the type, the stage and the source of the conflict. This paper focuses specifically on ethnic conflict. It argues that, irrespective of the sources of ethnic conflict, institutions are an important mediating factor in fuelling or reducing the potential for ethnic violence. It proposes to deepen the research on the institutional sources of conflict to understand how institutional change can alleviate ethnic tensions. The next section situates the argument within the broader debate on peacebuilding and conflict prevention. The paper then discusses institution-building in a multi-ethnic context. It will use the cases of Indonesia and Nigeria to illustrate the discussion. 


\section{..Spoiler Problems in Peace} Processes"

Steven Stedman

African Studies Department, SAlS

1740 Massachussetts Avenue, N.W.

Washington, D.C. 20036

USA

Phone: (202) 663-5681

Fax: (202)663-5683

Email:

sstedman@mail.jhuwash.jhu.edu

The greatest danger to peace processe comes from spoilers-leaders and parties who see peace as a threat to their power, world view, and interests, and use stealth or violence to undermine attempts to achieve it. When spoilers succeed, as they did in Angola in 1992 and Rwanda in 1994, the results are catastrophic. In both cases, the casualties of failed peace were infinitely higher than the casualties of the preceding war. The paper argues that spoilers differ by the goals they seek and their commitment to achieving those goals. External actors have a range of strategies available to them, from ones that rely heavily on conciliation to ones that rely heavily on coercion. The appropriateness of a particular strategy depends on the goa and commitment of the spoiler and the constraints posed by other parties in the peace process. Selection of a robust strategy requires that the custodian overcome various organizational and individual blinders that prevent it from accurately interpreting the intentions and behaviour of the spoiler. Implementation of a successful strategy depends on the ability of the custo

dian to create an external coalition for peace; the resources that the coalition brings to its responsibility; and the consensus that the coalition forms about the legitimacy or illegitimacy of spoiler demands and behaviour.

$$
\text { "An Early Warning about Forecasts: }
$$$$
\text { Oracle to Academics" }
$$

Dipak K. Gupta

School of Public Administration and Urban Studies

San Diego State University

San Diego, CA 92182-D367

USA

Phone: (619) 594-4067

Fax: (619)594-1165

Email: dgupta@mail.sdsu.edu

While we develop quantitative models for forecasting political and humanitarian crises, questions linger about their efficacy. In econometrics, there are accepted methodologies for determining the closeness of fit between the predicted and observed values. However, apart from the challenges of appropriate data and methods of analysis, many of these standard techniques either a) tell us little about the relative efficiency of our forecasting model or b) they do not even apply to the prescriptive models. This is because, first, after decades of economic forecasting, empirical evidence suggest that no single method predominates over others. Second, since EW models are for directing public policy, the predicted values are not independent of the observed values. That is, if a model places a nation on its list of highest risk, which provokes the intended policies for averting the crisis and the early actions are successful, then how do we measure the model's success? Therefore, in this paper, I emphasize that these models should not be considered as "forecasts" and should be taken as "warnings." II

\section{Breaking Ground: The 1956 Hungarian Immigration to Canada}

Edited by Robert H. Keyserlingk

TOrQJ,to: York Lanes Press, 1993( ISBN 1-55014-232-1, 117 pages, \$6.99

This book is a collection of personal and archival-based memories on the selection, transport and settlement of about 40,000 Hungarian refugees in Canada in one year.

\section{RECENT REPOI TS}

- Somali Refugees in

Toronto: A Proffie

By Edward Opokti-Dapaah ISBN 1-55014-278-x, $130 \mathrm{pp}$., $\$ 12.95$.

This is the fll'St comprehensive study of Somali refugees in Toronto. It examines the social! residential, and lingui,stic char. acteristic of Somalis, their participation in the local economy, and the activity of Somali community organizations. The report also contains valuable suggestions and rec. ommendations concerning suitable

more efficient service delivery to this com. munity.

.. bodianRefugees in. Oatario:

An EvaluatWnofResettlemeat and Adaptation

By Janet Mclellan,

ISBN 1-55014--267-4,142 pp., \$12.95.

'fbismajQrsttidyof CambOdian. -fugeesin Ontar10 examines the effects of various forms of sponsorship on Cambodian reset. tlement. It also focuses and the linguistic, economic, educa,tional, training and social tUmen $\$$ iQ1'!\$.of $\sim$ h Whqleproce, 5 \&qf adap, tation. The delivery of services by governmental and NGO agencies as well as the

effectS of the past traumatic experiences of genocideandma\$\$ta(Vation QJ\} Cambot;Uan.refijgeesat fijUy diScussed.

- Refugee Families awl ChiJdren: A Directory for Service Provide in

Metto T rou.to

Compiled by

Dr. John Monis and Lydia Sawicki. ISBNJ55014-285-2,39 pp., .\$6.95.

fhis di1'e(tory isdesignedJor service pro¥iqet\$wD9Pio - withJ geefamiliesand children ih Metr9 Toronto. ItS aim is to improve service provision through net. working and the sharing of training Oppor. tUnities

AWilable from Centre for Refugee Studies 


\section{CRSIYLP PUBLICATIONS} BOOKS

From Being Uprooted to Surviving: Resettlement of the VietnameseChinese "Boat People" in Montreal, 1980-1990

Lawrence Lam (1996) \$18.95

Asylum-A Moral Dilemma

W. Gunther Plaut (co-published with Praeger Publishers 1995) \$19.90

Refugee Rights: Report of a Comparative Survey James C. Hathaway and John A. Dent (1995) $\$ 11.95$

Legitimate and Illegitimate Discrimination: New Issues in Migration Edited by Howard Adelman (1995)

African Refugees: Development Aid and Repatriation Edited by Howard Adelman and John Sorenson (1994) $\$ 39.90$

Immigration and Refugee Policy: Australia and Canada Compared Edited by Howard Adelman, Lois Foster, Allan Borowski and Meyer Burstein (1994)

Volume One: Context, Policy and Implementation \$24.95 Volume

Two: Settlement and Impact \$24.95

Breaking Ground: The 1956 Hungarian Immigration to Canada Edited by Robert H.

Keyserlingk (1993) \$6.99

Taking Refuge: Lao Buddhists in North America Penny Van Esterik (1992) $\$ 12.95$

Refuge or Asylum: A Choice for Canada Edited by Howard Adelman and C. Michael Lanphier (1991) $\$ 18.95$

Refugee Policy: Canada and the United States Edited by Howard Adelman (1991) $\$ 20.95$

Soviet-Jewish Emigration and Resettlement in the 1990s Edited by Tanya Basok and Robert J. Brym (1991) \$4.99
REPORTS

Paths to Equity: Cultural, Linguistic, and Racial Diversity in Canadian Early Childhood Education Judith Bernhard, Marie Louise

Lefebvre et al. (1995) \$18.95

Cambodian Refugees in Ontario: An Evaluation of Resettlement and Adaptation Janet McLellan (1995) $\$ 12.95$

Somali Refugees in Toronto: A ProfJIe Edward Opoku-Dapaah (1995) \$12.95

Refugee Families and Children: A Directory For Service Providers in Metro Toronto John Morris and Lydia Sawicki (1995) \$6.95

Adaptation of Ghanaian Refugees in Toronto Edward Opoku-Dapaah (1993) \$12.50

Report on the Workshop for African Community Groups in Toronto Edward Opoku-Dapaah (1992) $\$ 12.50$

Directory of African Community Groups in Toronto Edward Opoku Dapaah (1992)

Occasional Papers

Fading Hopes: Struggles for Survival Among Cambodians Repatriated from Thai Refugee Camps Janet McLellan (1996) $\$ 13.95$

The Genesis of a Domestic Refugee Regime: The Case of Hungary Edited by Howard Adelman. Endre Sik and Giza Tessenyi (1994)\$14.95

So That Russia Be "Saved": AntiJewish Violence in Russia, Its Roots and Consequences Tanya Basok and Alexander Benifand (1993)

The Refugee Crisis in Russia Rozalina Ryvkina, Rostislav Turovskiy and Robert Brym (1993) \$9.95

Please send your orders to: Centre for Refugee Studies York University North York ON M3J IP 32ominated for the 1997 Chomas \&

Znamiecki Frize, to be amarbed in

Summer bp the 3nternational flligration section of the Ameritan Sociological gssociation

Paths To Equity

Cultural, Linguistic, and Racial Diversity in Canadian Early Childhood Education

by Judith K. Bernhard, Marie Louise Lefebvre, Gyda Chud and Rika Lange

Toronto: York Lanes Press ISBN 1-55014-277-1; 112 pages, size $8.5 \times 11 ; \$ 18.95$

Paths to Equity is based on an extensive nationwide study of 77 childcare centres in Montreal, Toronto, and Van couver on the cultural, linguistic, and racial diversity in Canadian Early Childhood Education (ECE). The report presents the results this study on how the ECE system is responding to the increasing diversity of contemporary Canadian society.

A fully one third of teachers interviewed in this study responded, at the time of graduation from ECE programs, did not feel that they were well prepared to work effectively with children and parents from diverse backgrounds. In this ground-breaking study, the authors have addressed teachers' views on diversity in the education programs; parents difficulties in collaborating within the current education system; teachers' difficulties in understanding many "ethnic" parents; desire of many parents for better communication with staff, preferably in their own languages, and for more information about their individual children, and chances for effective input; and the evidence of some continuing problems with racism, irrespective of the good intentions of centre staff.

Paths to Equity will be of interest to ECE faculty, policymakers, centre supervisors and staff and others interested in the inclusion of diversity content in professional education programs. 


\section{From Being Uprooted to Surviving: \\ Resettlement of \\ Vietnamese-Chinese \\ "Boat People" in \\ Montreal, 1980-1990 \\ By Lawrence Lam \\ Toronto: York Lanes Press ISBN 1-55014-296-8 \\ 200 pages, indexed; $\$ 18.95$}

The saga of the "boat people" is a dramatic story, a story of one of the largest refugee movements in recent years. Canada played a significant role in the resettlement of these refugees in bringing them to Canada where they could start anew. From Being Uprooted to Surviving by Professor Lam, is based on ethnographic data of a sample of Vietnamese-Chinese accepted for resettlement in Montreal in 1979 and 1980, who were interviewed again in 1984-85 and in $1990-91$, this book provides a longitudinal account of their experience of resettlement in Canada. This experience has been marked by successive stages of their struggle to overcome structural barriers and to negotiate a meaningful niche in Canada.

Contents: Preface, The Boat People Phenomenon, ResettlementIssues and Perspectives, The Vietnamese-Chinese Refugees, Exodus and Transition, Resettlement Process-The First Three Years, Resettlement-Beyond the First Three Years, Conclusion.

Please send your orders to:

Centre for Refugee Studies

York University

Suite 322, York Lanes

Keele Street 4700

North York ON M3J 1 P3

\section{Back Issues of Refuge}

The following is a list of general and thematic issues of Refuge-Canada's periodical on refugees.

1. Environmental Refugees, Vol.12, No.1, June 1992.

2. Discussion ofImmigration Bill C-86, Vol.12, No.2, July/(Aug.) 1992.

3. General Issue/Refugee Sponsorship, Vol.12, No.3, Sept. 1992.

4. Eastern European Refugees, Vol.12, No.4, Oct. 1992.

5. The Tragedy of Somalia, Vol.12, No.5, Nov./Dec. 1992

6. The Review of Rejected Refugee Claims in Canada, Vol.12, No.6, Jan. 1993. 7

Russia and Central Eurasia, Vol.12, No.7, February 1993.

8. Africa Issue: Repatriation, Vol.12, No.8, March 1993.

9. General Issue/Globalization, Vol.13, No.1, April 1993.

10. Russia and Central Eurasia, Vol.13, No.2, May 1993.

11. Special Issue on Sri Lanka, Vol.13, No.3, June 1993.

12. Gender Issues and Refugee Law, Vol.13, No.4, July/Aug. 1993.

13. Southeast Asian Refugees, Vol.13, No.5, Sept. 1993.

14. Mozambican Refugees, Vol.13, No.6, October 1993.

15. Russia and Central Eurasia, Vol.13, No.7, Nov./Dec. 1993.

16. General Issue/Sudan, Vol.13, No.8, January 1994.

17. Integration of Refugees-The Canadian Experience, Vol. 13, No.9, Feb. 1994. 18.

Refugees and Peace in Central America, Vol.13, No. 10, March 1994.

19. Horn of Africa, Vol.14, No.1, April 1994.

20. The Russian Federation, Vol.14, No.2, May 1994.

21. The Former Yugoslavia, Vol.14, No.3, June/July 1994.

22. General Issue/IRB and Rebuilding Trustrramil Immigrants in Canada,

Vol. 14, No.4, Aug./Sept. 1994.

23. Rwandan Crisis, Vol.14, No.5, October 1994.

24. Refugee Resettlement in Israel, Vol.14, No.6, Nov. 1994.

25. Refugee Women-Part 1: Issues, Vol.14, No.7, Dec. 1994.

26. Refugee Women-Part 2: Case Studies, Vol.14, No.8, Jan. 1995.

27. The Safe Third Country Concept, Vol.14, No.9, February 1995.

28. Special Issue on Chechnya, Vol.14, No. 10, March 1995.

29. Reformulation ofInternationai Refugee Law, Vol.15, No.1, 1996

30. Environment, Development and Refugees, Vol.15, No.2, 1996.

31. International Intervention in Refugee Crises, Vol.15, No.3, 1996.

32. Early Warning on Humanitarian Crises, Vol.15, No.4, 1996.

33. Special Issue on Child Refugees, Vol.15, No.5, 1996.

3. Special Issue on Global Settlement Services, Vol.15, No.6, 1997.

Single copy: Vol 12, 13 \&14-\$6.50; Vol 15-\$10. 10 percent discount on 3-9 issues (copies); 20 percent discount on 10 issues (copies) or more. Special discounts are available for students and exclusively volunteer-run NGOs. P. O. accepted.

Please send your orders to:

Centre for Refugee Studies, York University

Suite 333, York Lanes, 4700 Keele Street

North York, Ontario, M3J IP3, Canada

Fax: (416) $736-5837^{\bullet}$ Email: refuge@yorku.ca 


\section{call fOR papars}

(C) Susanne Schmeidl and Howard Adelman, 1997. This open-access work is licensed under a Creative Commons Attribution-NonCommercial 4.0 International License, which permits use, reproduction and distribution in any medium for non-commercial purposes, provided the original author(s) are credited and the original publication in Refuge: Canada's Journal on Refugees is cited. 

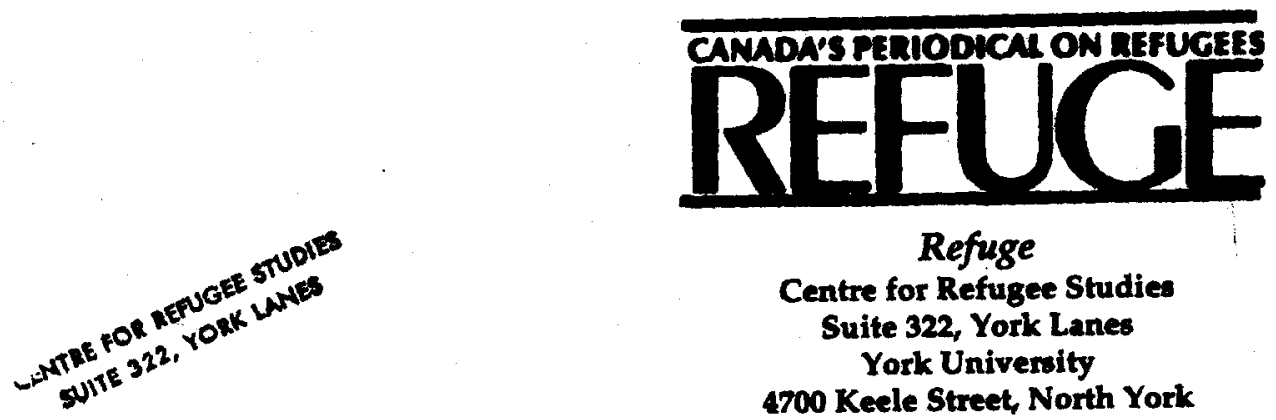

\section{Refuge}

Centre for Refugee Studies Suite 322, York Lanes

York University

4700 Keele Street, North York

Ontario, Canada M3J 1P3

Phone: (416) 736-5663

Fax: (416) 736-5837

Internet: refugegyorku.ca

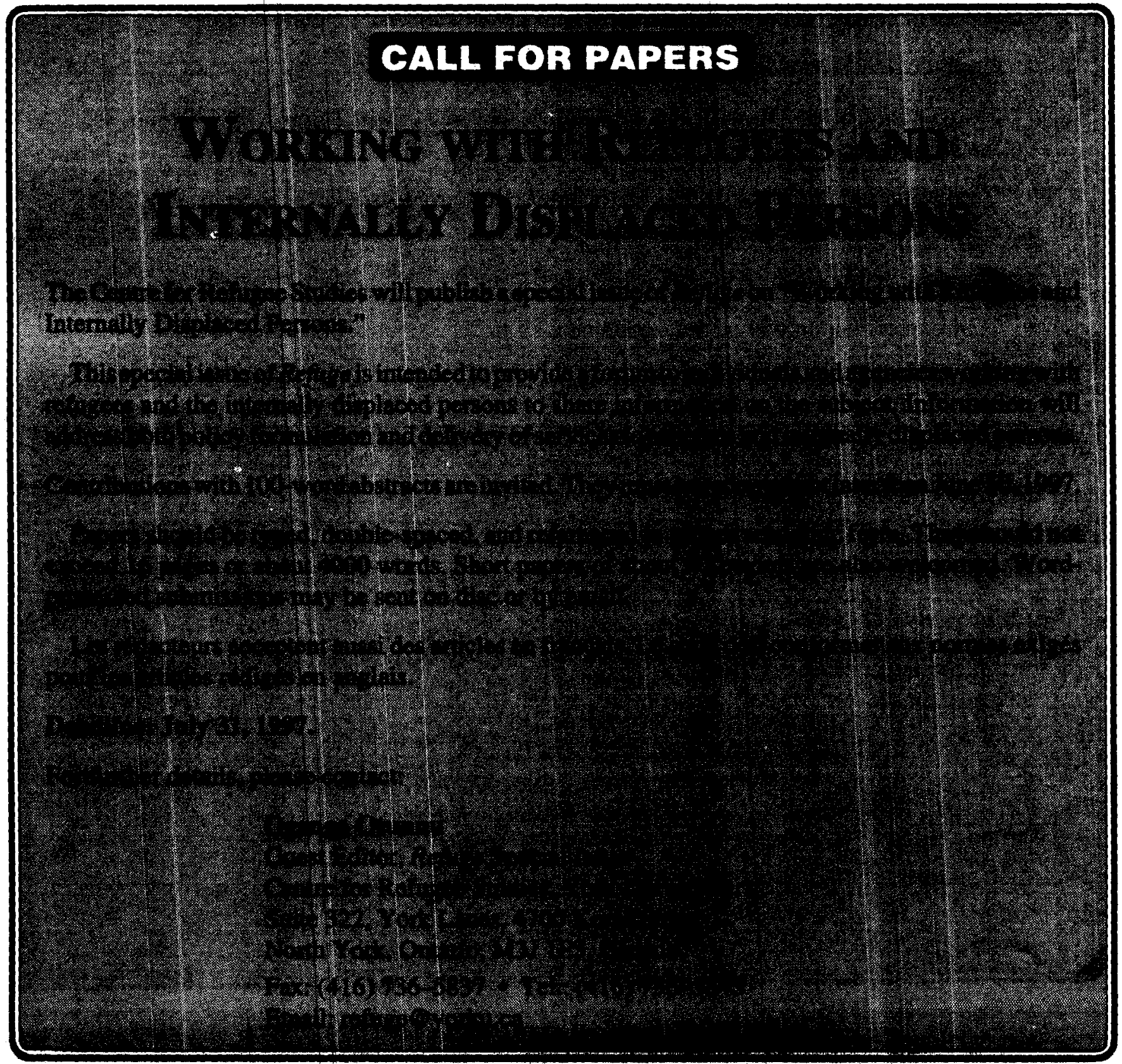

- (c) Susanne Schmeidl and Howard Adelman, 1997. This open-access work is licensed under a Creative Commons Attribution-NonCommercial 4.0 International License, which permits use, reproduction and distribution in any medium for non-commercial purposes, provided the original author(s) are credited and the original publication in Refuge: Canada's Journal on Refugees is cited. 